\title{
42. PLIOCENE-PLEISTOCENE PALEOENVIRONMENTAL HISTORY OF THE WESTERN MEDITERRANEAN: A SYNTHESIS OF ODP SITE 653 RESULTS ${ }^{1}$
}

\author{
D. Rio, ${ }^{2}$ R. Sprovieri, ${ }^{3}$ R. Thunell, ${ }^{4}$ C. Vergnaud Grazzini, ${ }^{5}$ and G. Glaçon ${ }^{6}$
}

\begin{abstract}
Micropaleontological and oxygen isotopic studies of ODP Site 653 provide a nearly continuous and detailed record of the Pliocene-Pleistocene paleoenvironmental history of the Tyrrhenian Sea. Although the planktonic fauna and flora indicate that relatively warm conditions prevailed in the Mediterranean during the early Pliocene, the oxygen isotopic and paleontologic records show that this was not a period of "stable" climatic conditions. The first indications of a cooling trend in this region occur at approximately $4.1 \mathrm{Ma}$ and $3.8 \mathrm{Ma}$ with the introduction of a warm-temperate planktonic foraminiferal fauna and a major change in the calcareous nannofossil assemblage.

The cooling trend is accentuated at approximately 3.1 Ma. At this time the warm water planktonic foraminiferal fauna is almost totally replaced by a temperate fauna, the cool water Coccolithus pelagicus shows a significant increase in abundance, and the oxygen isotope record shows a sudden cooling. During this part of the Pliocene, the benthic foraminiferal fauna present in the Tyrrhenian Sea was very similar to the deep water fauna of the adjacent North Atlantic suggesting the existence of deep water exchange between these basins.

The development of major Northern Hemisphere glaciation which has been well documented in the open ocean at approximately $2.4 \mathrm{Ma}$ can easily be recognized in the Site 653 oxygen isotope record and in the sharp reduction in productivity of the discoasterids. The anti-estuarine circulation that characterizes the modern Mediterranean appears to have been established at this time. Another significant cooling is observed across the Pliocene-Pleistocene boundary, with cool water planktonic foraminifera becoming the dominant component of the overall assemblage.

The Pleistocene $\delta^{18} \mathrm{O}$ record contains two modes of variability, a feature typical of open ocean records. The lower Pleistocene is dominated by low amplitude glacial/interglacial cycles, whereas the upper Pleistocene contains high amplitude fluctuations.
\end{abstract}

\section{INTRODUCTION AND BACKGROUND}

The results from previous deep sea drilling legs in the Mediterranean (DSDP Legs 13 and 42A) have contributed significantly to our understanding of the Neogene paleoclimatic and paleoceanographic history of this region. Of the many holes drilled during these two legs, Site 132 in the Tyrrhenian Basin was the only site to recover a moderately complete PliocenePleistocene sequence (Ryan, Hsü, et al., 1973). Consequently, extensive micropaleontological (Ciaranfi and Cita, 1973; Cita et al., 1973; Thunell, 1979; Raffi and Rio, 1979), sedimentological (Chamley, 1975 and 1983), and stable isotopic studies (Longinelli and Cita, 1973; Thunell and Williams, 1983) were carried out on material from this site, and provided the most detailed paleoenvironmental record available for the Pliocene-Pleistocene of the western Mediterranean.

The primary objective of ODP Site 653 was to reoccupy Site 132 in order to recover a continuous, undisturbed Pliocene-Pleistocene sedimentary sequence that would serve as a "deep-sea type section" for both stratigraphic and paleoenvironmental studies (Shipboard Scientific Party, 1987). Site 653 was located less than $1 \mathrm{~km}$ from DSDP Site 132, on the edge of the Cornaglia Terrace in the western Tyrrhenian Basin. Two holes (653A and $653 \mathrm{~B}$ ) were cored at this site using the advanced piston corer

\footnotetext{
${ }^{1}$ Kastens, K. A., Mascle, J., et al., 1990. Proc. ODP, Sci. Results, 107: College Station, TX (Ocean Drilling Program).

2 Istituto di Geologia, Universita degli Studi di Parma, Vialle delle Scienze, 43100 Parma, Italy.

3 Istituto di Geologia, Corso Tukory 131, 90134 Palermo, Italy.

4 Department of Geological Sciences, University of South Carolina, Columbia, SC 29208.

5 Department de Geologie Dynamique, Universite Pierre et Marie Curie, 4 Place Jussieu, 75252 Paris Cedex 05, France.

6 Laboratoire de Stratigraphie et de Paleoecologie, Universite de Provence, 13331 Marseille, France.
}

(APC) and extended core barrel system (XCB). Recovery of Pliocene-Pleistocene sediments for both holes was excellent, and in particular recovery for Hole $653 \mathrm{~A}$ averaged $100 \%$ while piston coring and $88 \%$ while XCB coring (Shipboard Scientific Party, 1987).

Site 653 will undoubtedly serve as a basis for many high resolution paleoenvironmental studies in the years to come. In this chapter, we attempt to integrate and synthesize some of the paleoenvironmental contributions included in this Leg 107 volume. Although Site 653 did not yield a good magnetostratigraphy (Channell et al., this volume), it can be biostratigraphically correlated to Site 652 which did contain a good polarity stratigraphy (Rio, Raffi, and Villa, this volume). The calcareous plankton biochronology established for Site 653 by Rio et al. (this volume) and Glacon et al. (this volume) provides the time framework for interpreting the paleoenvironmental history of the western Mediterranean. An age-depth plot of the various plankton bioevents clearly indicates that sedimentation rates have been fairly uniform at Site 653 during the Pliocene-Pleistocene (Fig. 1). The only gap, in an otherwise continuous record, is a brief hiatus just before the Pliocene-Pleistocene boundary. Thus, Site 653 is an ideal section for deciphering the post-Messinian paleoclimatic and paleoceanographic history of the Mediterranean.

\section{MAJOR RESULTS}

The paleoenvironmental record contained in Site 653 sediments is a complex mixture of three distinct signals: (1) global climate change, (2) regional climate change, and (3) the tectonic history of the Tyrrhenian Basin. The results from ODP Leg 107 clearly indicate that the Tyrrhenian Sea is a very young basin which only began to form in the late Miocene (Tortonian) (Shipboard Scientific Party, 1987). The Cornaglia Terrace on which Site 653 was located has subsided over $2,000 \mathrm{~m}$ during the Pliocene-Pleistocene. The dramatic change in paleodepth of this re- 


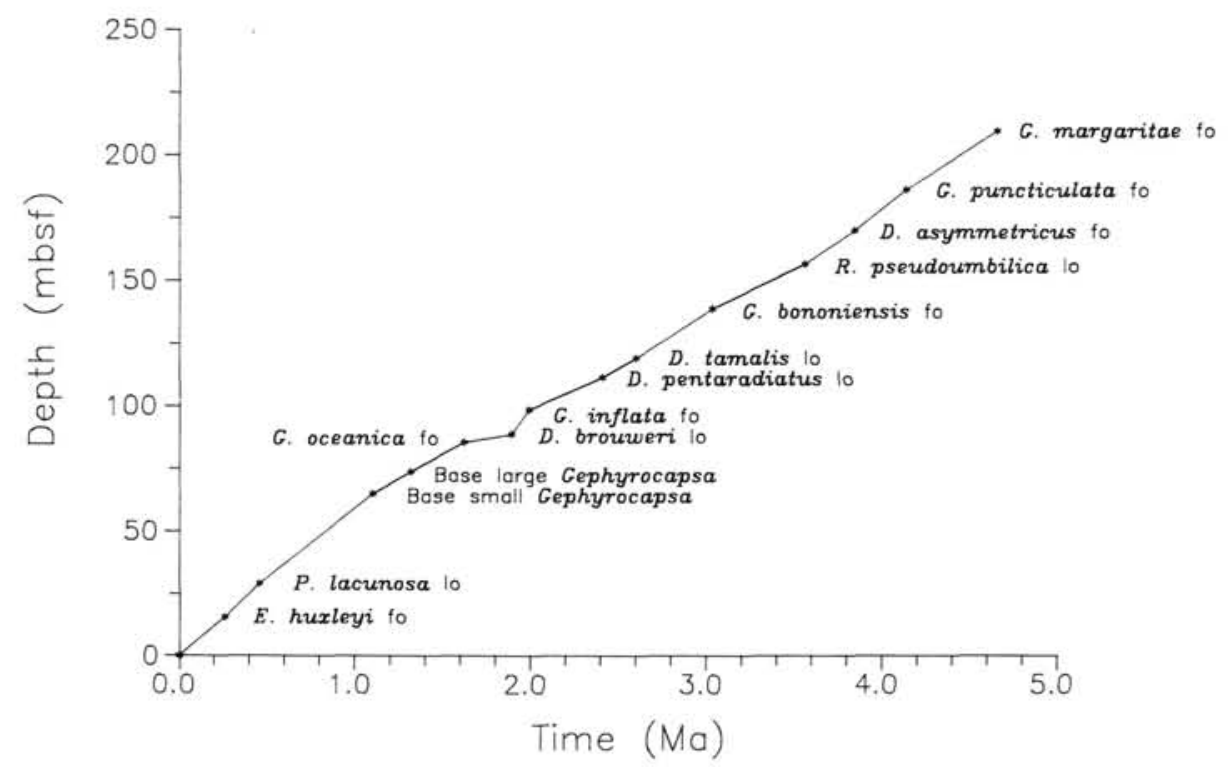

Figure 1. Age vs. depth plot for ODP Site 653. The biostratigraphic datums used to construct this plot are from Rio et al. (this volume) and Glaçon et al. (this volume).

gion undoubtedly had a major impact on the succession of benthic faunas.

This synthesis is based primarily on a number of studies carried out on material from Site 653 and reported on in this volume, including: the planktonic foraminiferal work of Glaçon et al. (Fig. 2), the benthic foraminiferal work of Hasegawa et al. (Table 1), the calcareous nannofossil study of Rio, Raffi, and Villa (Fig. 3), and the oxygen isotopic studies of Thunell et al. (this volume) (Fig. 4) and Vergnaud Grazzini et al. (this volume) (Figs. 4 and 5). The major paleoenvironmental results obtained from Site 653 are summarized in the following sections and in Figure 6.

\section{Early Pliocene (4.9-3.6 Ma)}

In the earliest Pliocene the Tyrrhenian Sea was a relatively shallow open marine basin. The benthic foraminiferal faunas present at Sites 652, 653, and 654 during MPI1 are indicative of upper epibathyal water depths (200-600 m) (see Table 1 and Fig. 6 ). Continued subsidence of the basin during the early Pliocene resulted in the establishment of a lower epibathyal (600-1200 m) benthic fauna during MPI2 and MPI3 (Fig. 6). The benthic foraminiferal faunas present in the Tyrrhenian Sea during the early Pliocene were most likely derived from the adjacent Atlantic margin. During this time interval there appears to have been only a minor introduction of benthic foraminiferal species typically associated with deep Atlantic water masses (Hasegawa et al., this volume). Previous work of Van der Zwaan (1983) indicates that the benthic fauna that repopulated the Mediterranean in the earliest Pliocene was quite similar to the fauna that existed prior to the Messinian salinity crisis.

The early Pliocene is often referred to as a time of warm, stable global climate (Keigwin, 1982, 1987; Hodell and Kennett, 1986). The planktonic foraminiferal fauna does indeed suggest that surface water conditions in the Tyrrhenian Sea were relatively warm during most of the early Pliocene (Fig. 2). The planktonic assemblage during this interval is dominated by species of Globigerinoides and keeled Globorotalia, two genera typical of modern low latitude regions (see Glaçon et al., this volume). These findings are consistent with those of Zachariasse and Spaak (1983), in which they reported that the lower Pliocene interval of numerous outcrop sections in Crete and Sicily was dominated by subtropical planktonic foraminifera. At this time, the tropical-subtropical province in the eastern North Atlantic extended to at least $35^{\circ} \mathrm{N}$, easily facilitating the introduction of this warm water assemblage into the Mediterranean (Thunell and Belyea, 1982).

Within the Mediterranean, the characterization of the early Pliocene as a time of stable climatic conditions might not be entirely accurate. As can be seen in Figure 2, the relative abundances of the warm water planktonic foraminiferal species ( $\mathrm{Glo}$ bigerinoides obliquus and $G$. quadrilobatus) do fluctuate considerably during the early Pliocene, suggesting that surface water conditions were not uniform throughout this interval. This is strongly supported by the Orbulina universa oxygen isotope record (Fig. 4). The entire early Pliocene interval of Hole 653A is marked by high amplitude (1.5\%), quasi-periodic fluctuations in $\delta^{18} \mathrm{O}$. The magnitudes of these fluctuations are considerably larger than the $0.5 \% 0$ oscillations that typify early Pliocene North Atlantic records (Shackleton et al., 1984; Keigwin, 1987). At most, only a small fraction of the $1.5 \% 0 \delta^{18} \mathrm{O}$ oscillations could be a function of ice volume, thus requiring significant temperature and/or salinity changes in the Mediterranean during the early Pliocene. These high amplitude fluctuations are not seen in the $G$. bulloides $\delta^{18} \mathrm{O}$ record because of the sparse sampling within the early Pliocene interval (Fig. 4). However, fluctuations of similar amplitude are present in the $G$. ruber $\delta^{18} \mathrm{O}$ record for this site reported on by Vergnaud Grazzini et al. (this volume).

By the latter part of the early Pliocene (MPI3) there is evidence for the beginning of a cooling trend in the Tyrrhenian $\mathrm{Ba}$ $\sin$. At approximately $4.1 \mathrm{Ma}$ we see the first occurrence of the warm-temperate planktonic foraminifer $G$. puncticulata (a member of the $G$. inflata group) concomitant with a decrease in abundance of $G$. obliquus (Fig. 2). At approximately $3.8 \mathrm{Ma}$, another change occurs in planktonic foraminiferal fauna with a further decline in the dominance of warm water forms and the establishment of $G$. ruber (Fig. 2). At this time a significant change in the calcareous nannofossil assemblage occurs (Fig. 3). Specifically, cooler water discoasterids $(D$. asymmetricus and $D$. tamalis) replace the warm water $D$. pentaradiatus and the warm water sphenoliths are strongly reduced in abundance (Fig. 3).

\section{Late Pliocene (3.6-1.66 Ma)}

The surface water cooling trend that began at the end of the early Pliocene continued into the late Pliocene, with a major 


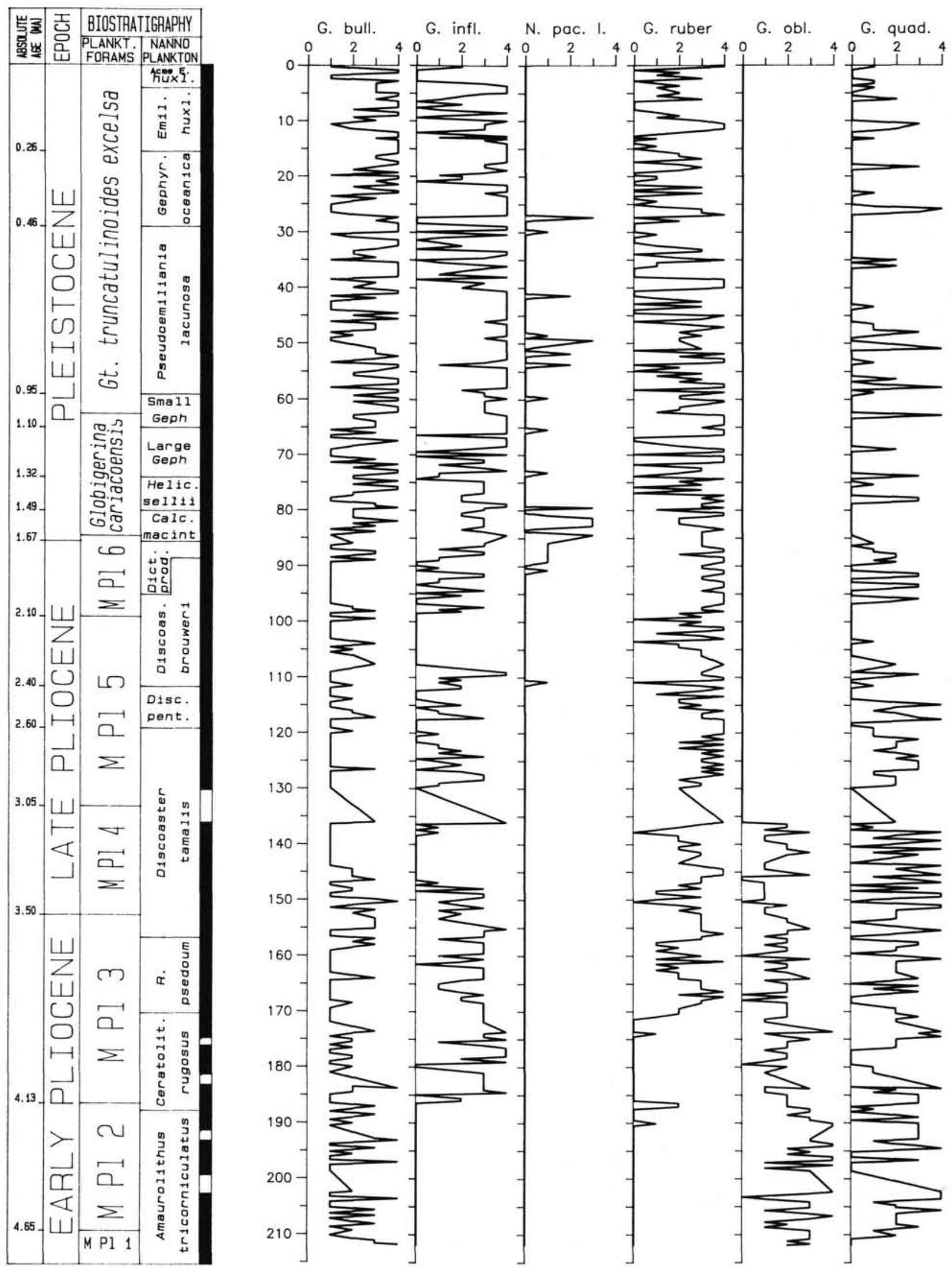

Figure 2. Changes through time in abundance patterns of selected planktonic foraminiferal groups of similar ecologic preference for ODP Site 653. The $G$. inflata group includes the nominate species, $G$. puncticulata and $G$. bononiensis. The G.ruber group includes, besides the nominate species, G. elongatus cyclostomus. The $G$. quad group includes $G$. quadrilobatus, $G$. sacculifer, and $G$. obliquus s.l. The abundance values, derived from Glaçon et al. (this volume), are as follows: $0=$ Absent, $1=$ Rare $(0 \%-3 \%), 2=$ Few $(3 \%-15 \%), 3=$ Common $(15 \%-30 \%)$, and $4=$ Abundant $(>30 \%)$. The time scale is from Rio, Raffi, and Villa (this volume). 
Table 1. Benthic foraminiferal assemblages and interpreted paleobathymetry (based on Hasegawa and others, this volume).

\begin{tabular}{llc}
\hline \multicolumn{1}{c}{ Assemblage } & Characteristic taxa & $\begin{array}{c}\text { Paleobathymetry } \\
(\mathrm{m})\end{array}$ \\
\hline 1. Upper Epibathyal & $\begin{array}{c}\text { costate Uvigerina, Globocassidu- } \\
\text { lina } \text { spp. }\end{array}$ & $200-600$ \\
2. Lower Epibathyal & $\begin{array}{c}\text { Siphonina reticulata, Parrel- } \\
\text { loides spp. }\end{array}$ & $600-1200$ \\
3. Upper Mesobathyal & $\begin{array}{c}\text { Oridorsalis spp., Cibicidoides } \\
\text { spp., Miliolina }\end{array}$ & $1200-1800$ \\
4. Middle Mesobathyal & $\begin{array}{c}\text { Miliolina, Gyroidina } \text { spp. } \\
\text { 5. Lower Mesobathyal }\end{array}$ & $\begin{array}{c}1800-2500 \\
2500\end{array}$ \\
\hline
\end{tabular}

cooling event occurring at approximately 3.1 Ma. At this time there was an abrupt and permanent decrease in the abundance of warm water planktonic foraminifera, and a concomitant increase in temperate water species (introduction of the Globorotalia bononiensis component of the G. inflata group) (Fig. 2). This surface water cooling and associated turnover in planktonic foraminifera was previously recognized in micropaleontological studies of DSDP Site 132 (Ciaranfi and Cita, 1973; Thunell, 1979) and land-based marine sections in southern Italy (Zachariasse and Spaak, 1983). Another manifestation of this surface water cooling which began at the end of the early Pliocene and continued through the late Pliocene is the sudden increase in the productivity of Coccolithus pelagicus, a species presently restricted to cool water masses (McIntyre and Be, 1967) (Fig. 3). Oxygen isotope records for Site 132 (Thunell and Williams, 1983) and Site 653 (Thunell et al., this volume; Vergnaud Grazzini et al., this volume) also show evidence for a cooling at this time. $O$. universa and $G$. bulloides oxygen isotope records for Hole $653 \mathrm{~A}$ are marked by increases of $1.0 \%$ and $0.5 \%$, respectively, at approximately $3.1 \mathrm{Ma}$ (Fig. 4).

Open ocean isotope records show a similar event that has been dated at 3.0-3.2 Ma (Shackleton and Opdyke, 1977; Keigwin, 1979, 1982, and 1987; Prell, 1984; Shackleton et al., 1984). Based on the lack of covariance between planktonic and benthic $\delta^{18} \mathrm{O}$ records, Prell (1984) concluded that this 3.2-3.0 Ma event was due to a climatic cooling without an associated increase in ice volume. More recently, Keigwin (1987) suggested that at least part of the enrichment in $\delta^{18} \mathrm{O}$ that occurred at this time was due to a glacial advance.

From 3.0 to $2.4 \mathrm{Ma}$, the planktonic foraminiferal assemblage is dominated by a warm-temperate water fauna ( $G$. ruber and $G$. bononiensis) (Fig. 2). Within the upper part of this interval the oxygen isotope records contain significant increases in $\delta^{18} \mathrm{O}$ values. Specifically, the 0 . universa record increases from $-1.0 \%$ at $2.7 \mathrm{Ma}$ to nearly $1.0 \%$ at $2.4 \mathrm{Ma}$ (Fig. 4). Similarly, the $G$. bulloides record contains a $1.5 \%$ enrichment in $\delta^{18} \mathrm{O}$ between 2.6 and $2.4 \mathrm{Ma}$ (Fig. 4). Above $2.5 \mathrm{Ma}$, the G. bulloides $\delta^{18} \mathrm{O}$ record for Hole $653 \mathrm{~A}$ is on average $0.9 \% 0$ heavier than the interval below this level. This change in the nature of the $\delta^{18} \mathrm{O}$ record at 2.4 Ma was previously observed in DSDP Site 132 (Thunell and Williams, 1983). Based on the timing of this event, we consider it to be equivalent to the $2.4 \mathrm{Ma}$ event recorded in the open ocean and attributed to a major build-up of Northern Hemisphere glaciation and the onset of the glacial/interglacial cycles (Shackleton et al., 1984; Keigwin, 1987).

The intensification of Northern Hemisphere glaciation at approximately $2.4 \mathrm{Ma}$ and the associated climatic cooling is welldocumented in European pollen records (Zagwin, 1974; Cravatte and Suc, 1981; Suc, 1984). These pollen records also indicate that parts of the Mediterranean region became much more arid at this time. An increase in aridity would have led to greater evaporation, and this in turn may have resulted in a negative water balance between the Mediterranean and the Atlantic. Under such circumstances an anti-estuarine flow would have been established between the two basins (inflow of Atlantic water at the surface and outflow of Mediterranean water at depth). Thus, the inception of the modern hydrographic regime in the Mediterranean may have come in response to the build-up of Northern Hemisphere glaciation and its impact on regional climatic conditions. This scenario is supported by the recent isotopic study of Loubere (1987) in which he first recognized the presence of a "Mediterranean outflow water" in the Atlantic at approximately $2.4 \mathrm{Ma}$.

The abundance of discoasters in Site 653 decreases abruptly in conjunction with this cooling at 2.4-2.5 Ma (Fig. 3). In particular, the last occurrences of Discoaster pentaradiatus and $D$. surculus are associated with this event. Above $2.4 \mathrm{Ma}$ discoasters occur sporadically until totally disappearing at about $1.8-$ $1.9 \mathrm{Ma}$ (Fig. 3). During this period the discoaster flora is composed entirely of $D$. brouweri, and its presence may reflect brief warming periods in the Mediterranean. For the North Atlantic, Backman and Pestiaux (1986) observed similar features in the discoaster record and interpreted them as responses to the buildup of Northern Hemisphere glaciation and subsequent glacial/ interglacial cycles. During the upper part of the late Pliocene $(2.5-1.7 \mathrm{Ma})$, the two oxygen isotope records for Hole $653 \mathrm{~A}$ show somewhat different patterns (Fig. 4). The G. bulloides record contains low amplitude $(0.5 \% 0-1.0 \% 0)$ oscillations, whereas the 0 . universa record contains a 300,000-year interval (from 2.4 to $2.1 \mathrm{Ma}$ ) during which $\delta^{18} \mathrm{O}$ values are fairly light and variability is low. Above $2.1 \mathrm{Ma}$, the $G$. universa record acquires a character that is more similar to the G. bulloides record (Fig. 4).

No major turnover in the planktonic foraminiferal fauna occurs in association with the climatic change at approximately $2.4 \mathrm{Ma}$. However, by approximately $2.0 \mathrm{Ma}$ cool water species (i.e., $G$. bulloides and $G$. inflata) begin to make a significant contribution to the total assemblage (Fig. 2). The incursion of these cool water forms into the Mediterranean was facilitated by the southerly expansion of the subpolar province along the eastern margin of the North Atlantic at this time (Thunell and Belyea, 1982).

The benthic foraminiferal fauna indicates that substantial subsidence of the Tyrrhenian basin occurred during the late Pliocene (Hasegawa et al., this volume). A lower epibathyal assemblage $(600-1200 \mathrm{~m})$ characterizes the beginning of the late Pliocene (MP14). Continued deepening of the basin resulted in the establishment of an upper mesobathyal assemblage (1200-1800 m) during MPl5 and MPl6 (Fig. 6). The upper mesobathyal assemblage is comprised of Oridorsalis spp., Cibicides spp., and Miliolina (Table 1). This assemblage is similar to that presently found on the slope and rise off western North Africa (Lutze and Coulbourn, 1983).

\section{Pliocene/Pleistocene Boundary (1.66 Ma)}

Historically, many workers have recognized and continue to recognize the Pliocene/Pleistocene boundary on the basis of climatic criteria. This concept can be traced to Forbes' (1846) association of the onset of Northern Hemisphere glaciation with the beginning of the Pleistocene. As we have already discussed, numerous well-dated oxygen isotope records indicate that the initiation of major northern hemisphere ice sheets began approximately $2.4 \mathrm{Ma}$ (Shackleton et al., 1984; Keigwin, 1987).

The most commonly used age estimates for the Pliocene/ Pleistocene boundary are considerably younger than $2.4 \mathrm{Ma}$ (Berggren et al., 1985). In particular, paleomagnetic dating of the newly accepted boundary stratotype section in Vrica (Calabria, southern Italy) places the Pliocene/Pleistocene boundary at approximately 1.66 Ma (Tauxe et al., 1983). Clearly, the boundary is not associated with the development of major Northern Hemisphere glaciation, and open ocean records do not indi- 


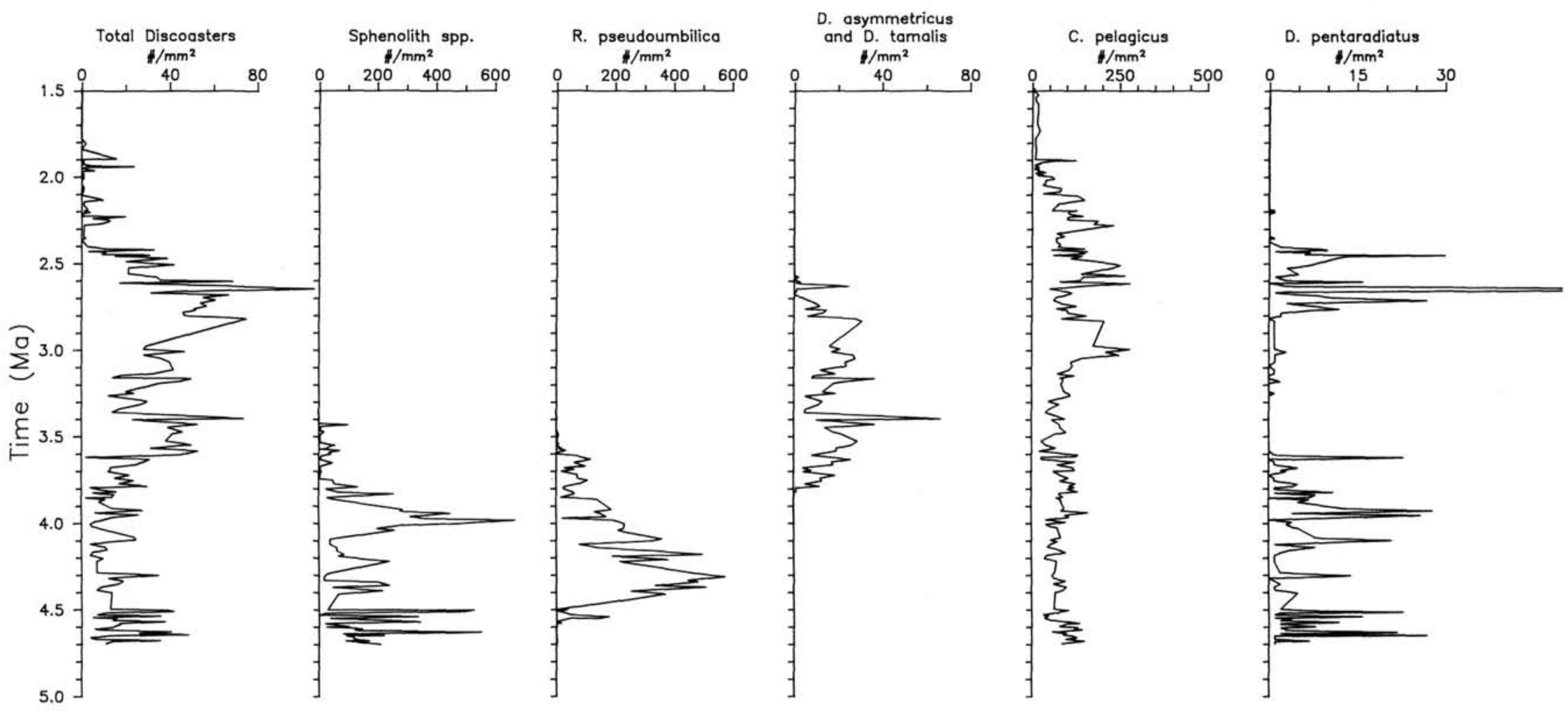

Figure 3. Changes through time in the abundances of selected calcareous nannofossil taxa for ODP Site 653 (based on Rio et al., this volume). 

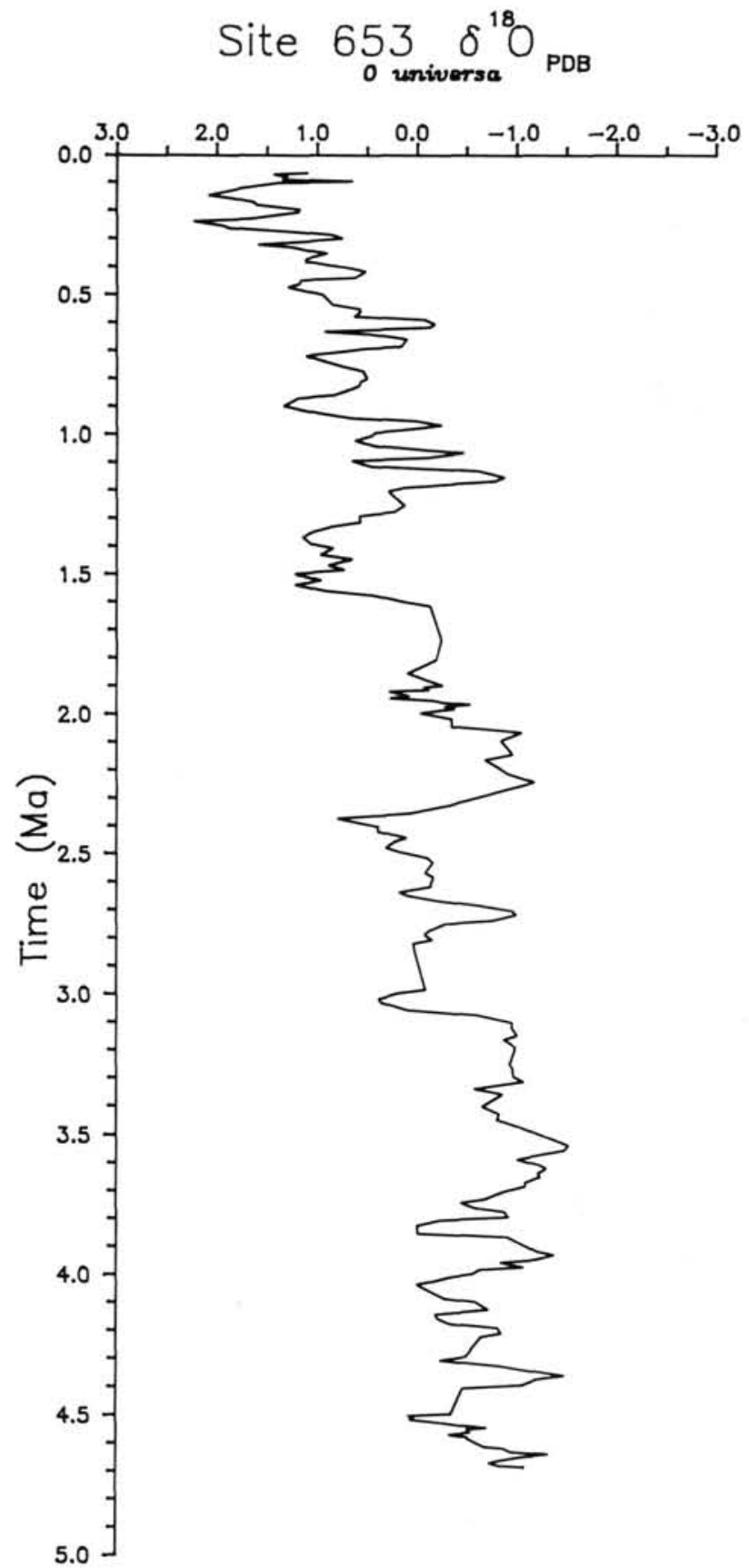
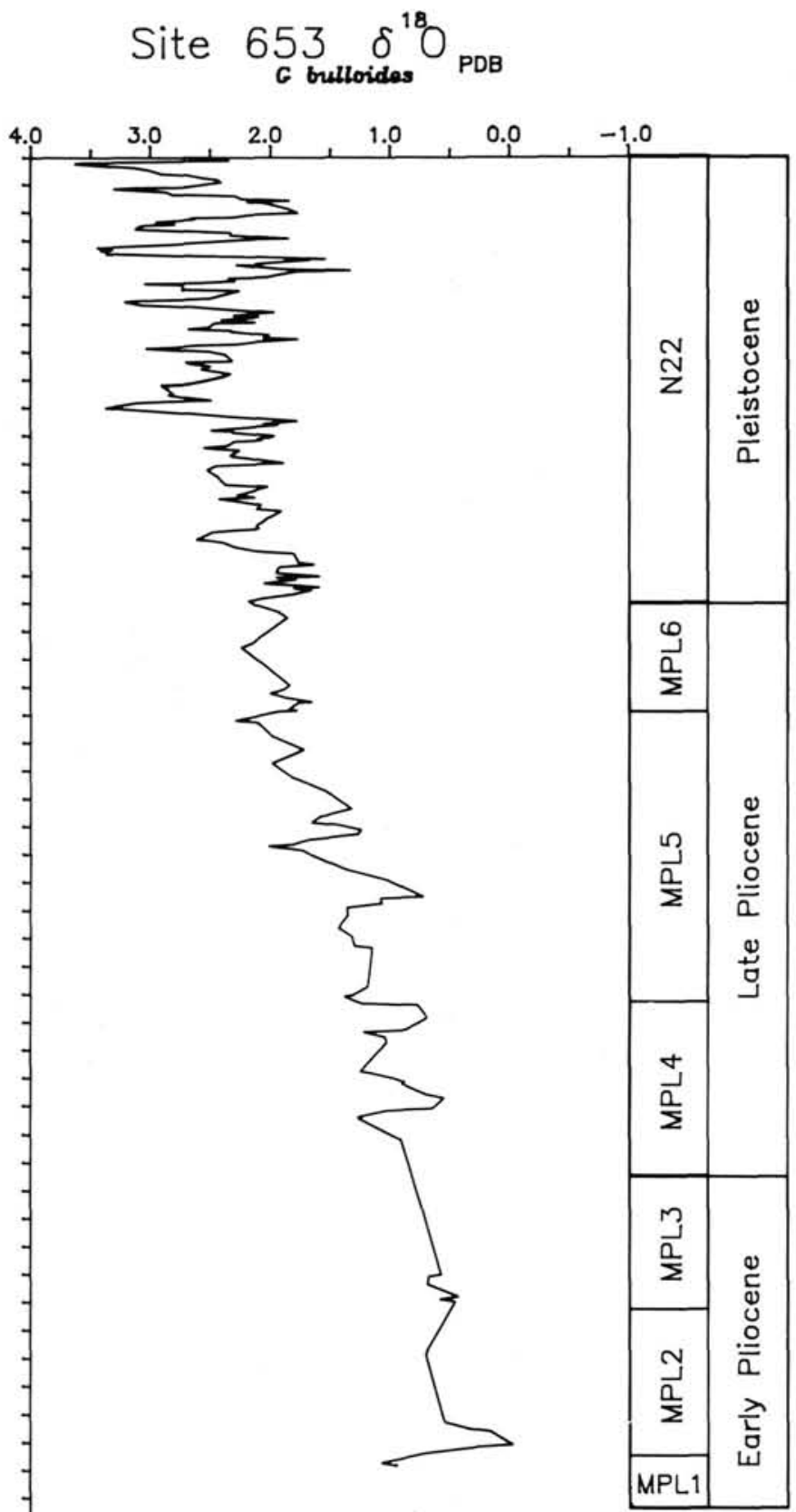

Figure 4. Planktonic foraminiferal oxygen isotope records for ODP Site 653 plotted to time. The $O$. universa record is from Thunell et al. (this volume) and the $G$. bulloides record is from Vergnaud Grazzini et al. (this volume). The time scale is from Rio et al. (this volume).

cate that the Pliocene/Pleistocene boundary was marked by any significant climatic change.

The Mediterranean appears to be an exception to this situation in that a regional cooling event does occur across the Pliocene/Pleistocene boundary. The first appearance of the cold water mollusk Arctica islandica in the Mediterranean is coeval with the boundary marker bed in the Vrica section (Pasini et al., in press). The planktonic foraminiferal fauna from Hole 653A shows a shift in dominance near the Pliocene/Pleistocene boundary, with cool water species (and $G$. bulloides) becoming dominant above this level (Fig. 2). The $O$. universa $\delta^{18} \mathrm{O}$ record also shows a sharp cooling across the boundary (Fig. 4).

\section{Pleistocene (1.66 Ma-Present)}

The western part of the Tyrrhenian Basin in the vicinity of Site 653 subsided $600-800 \mathrm{~m}$ during the Pleistocene (Hasegawa et al., this volume). During this interval the late Pliocene upper mesobathyal fauna was initially replaced by a middle mesobathyal and finally a lower mesobathyal benthic foraminiferal assemblage (Table 1, Fig. 6). The middle mesobathyal fauna of the early Pleistocene continued to maintain some affinity with the deep water fauna of the adjacent North Atlantic (Hasegawa et al., this volume). The introduction of Articulina tubulosa at the beginning of the Pleistocene may indicate the presence of re- 


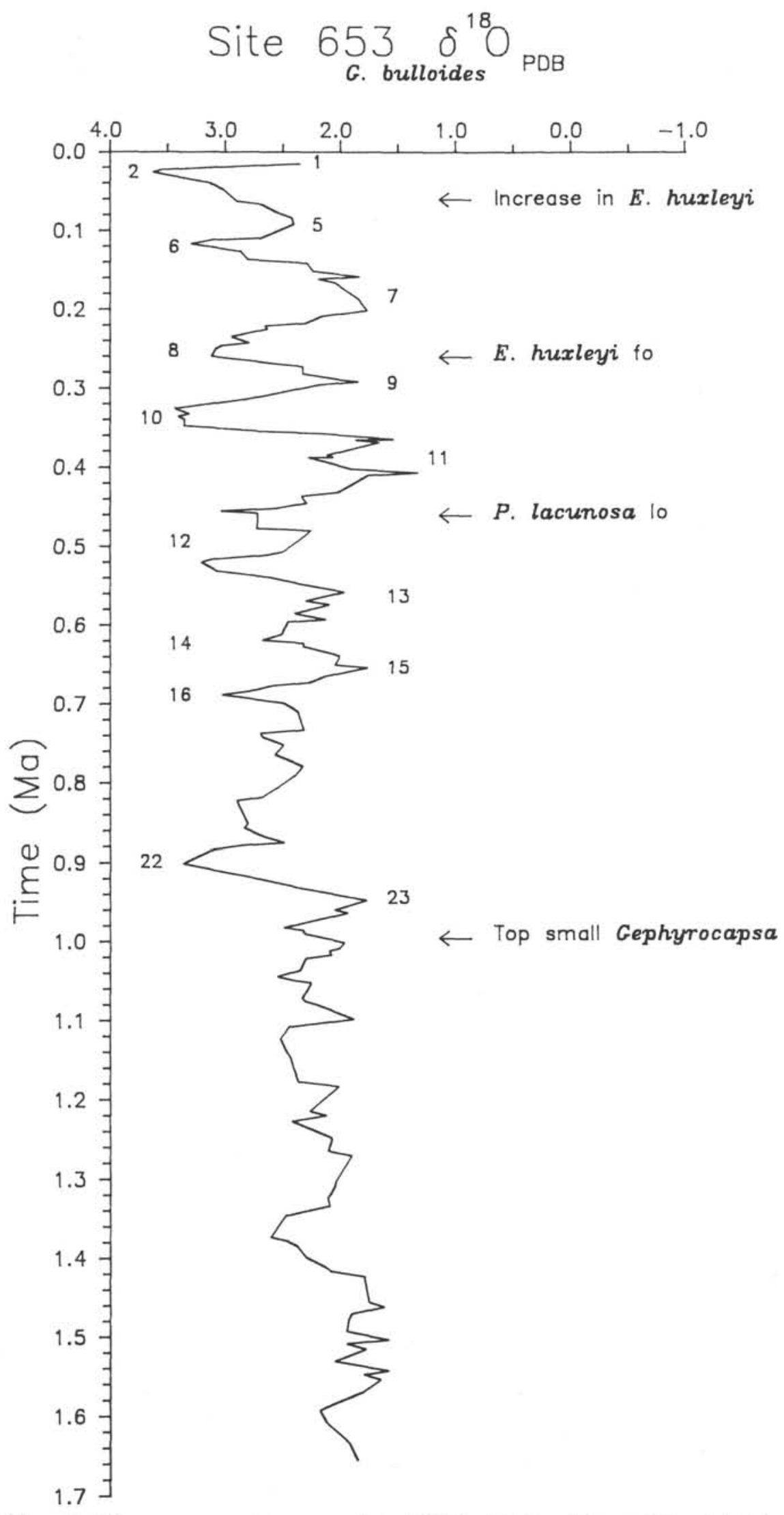

Figure 5. Pleistocene oxygen isotope record for ODP Site 653 (from Vergnaud Grazzini et al. this volume). For the upper part of the record individual oxygen isotope stages have been identified. The stratigraphic position of two calcareous nannoplankton events is also indicated (based on data from Rio et al., this volume). 


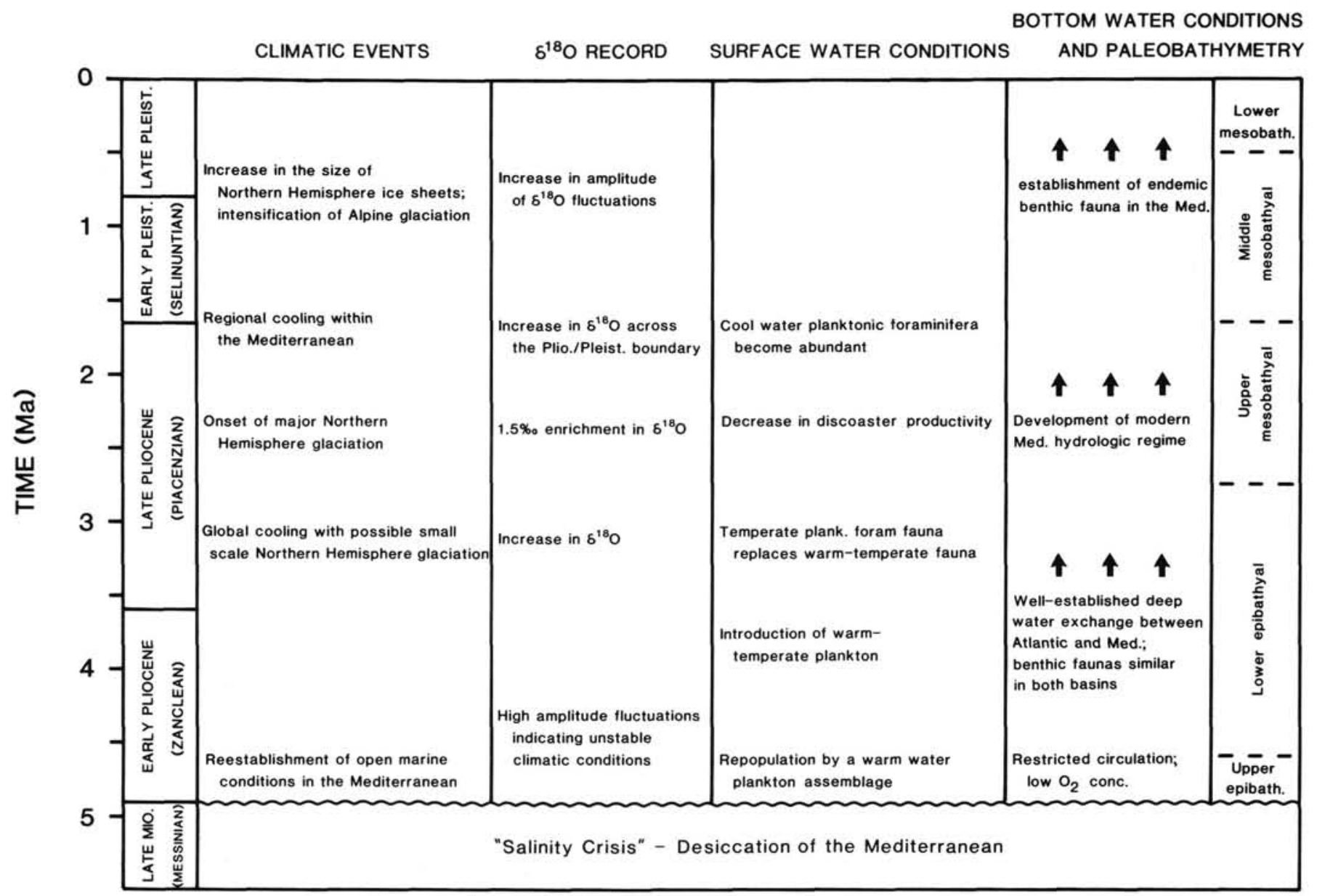

Figure 6. Summary of paleoenvironmental results for ODP Site 653 from the Tyrrhenian Sea and their relationship to global climatic changes.

duced bottom water oxygen conditions, a feature characteristic of the present Mediterranean. The highly specialized benthic foraminiferal fauna which characterizes the present day Mediterranean (Massiota et al., 1976; Cita and Zocchi, 1978) appears to have been fully established by the middle to late Pleistocene.

The Pleistocene planktonic foraminiferal fauna in the Tyrrhenian basin is dominated by a cool water assemblage (Fig. 2). Oscillations in the importance of this assemblage reflect glacial/ interglacial changes in surface water temperatures, with incursions of warm-temperate water forms during interglacial episodes.

The well-established late Pleistocene oxygen isotope stages (Emiliani, 1966; Shackleton and Opdyke, 1973) can, for the most part, be recognized in the $G$. bulloides $\delta^{18} \mathrm{O}$ record for Hole 653A (Fig. 5). Thierstein et al. (1977) have demonstrated that in the open ocean the first occurrence of $E$. huxley $i$ and the last occurrence of D. lacunosa occur within isotope stages 8 and 12 , respectively. Our results for Hole $653 \mathrm{~A}$ indicate that this relationship also holds true for the Mediterranean. The only section of the Hole 653A record in which individual isotope stages are difficult to recognize is the interval between stages 16 and 22 (Fig. 5).

The Pleistocene oxygen isotope record for Hole 653A clearly shows two distinct modes of climatic variability (Fig. 5). Between approximately 1.6 and $0.9 \mathrm{Ma}$, the $\delta^{18} \mathrm{O}$ record is characterized by low amplitude (less than $1.0 \%$ ) glacial/interglacial cycles. In contrast, the last 900,000 years was a period of high amplitude $(\sim 1.5 \%) \delta^{18} \mathrm{O}$ fluctuations. Not only is there a change in the amplitude of the glacial/interglacial $\delta^{18} \mathrm{O}$ signal at this time, but the absolute $\delta^{18} \mathrm{O}$ values of upper Pleistocene glacial intervals are considerably heavier than lower Pleistocene glacials.

This change in the character of the $\delta^{18} \mathrm{O}$ signal in the middle Pleistocene is typical of open ocean records (Shackleton and Opdyke, 1973; Pisias and Moore, 1981; Prell, 1982; Ruddiman et al., 1986, 1987; Williams et al., 1988). Ruddiman et al. (1986) have demonstrated that the dominant periodicity of glacial/interglacial cycles during the late Pliocene and early Pleistocene was 41,000 years. In contrast, the variance of the late Pleistocene $\delta^{18} \mathrm{O}$ signal is predominantly at a period of about 100,000 years (Shackleton and Opdyke, 1973; Pisias and Moore, 1981; Ruddiman et al., 1986). There is also an increase in the amplitude of the late Pleistocene $\delta^{18} \mathrm{O}$ signal, and this must reflect an increase in glacial ice volume during this interval. This striking change in the amplitude and frequency of Pleistocene ice volume changes occurs at the oxygen isotope stage $22 / 23$ boundary (Shackleton and Opdyke, 1973, 1976). Ruddiman et al. (1986) and Ruddiman and Raymo (1988) concluded that this midPleistocene shift in climatic regimes could not simply be a response to a change in insolation. Instead, they speculated that rapid mountain building may have intensified the meridional circulation of the atmosphere, which in turn would have decreased the ablation of ice in high latitudes. Within the Mediterranean region, the expansion of Alpine glaciation in the midPleistocene (Selli, 1967) is a manifestation of this global intensification of glacial conditions.

Another more subtle change occurs in the late Pleistocene portion of the Site 653 oxygen isotope record. Above Stage 12 
the glacial/interglacial cycles are more well-defined and of slightly larger amplitude than those of the previous 400,000 years (Fig. 5). This change in the character of the Mediterranean $\delta^{18} \mathrm{O}$ record at approximately $0.45 \mathrm{Ma}$ is also evident in composite records generated for the open ocean (Imbrie et al., 1984; Prell et al., 1986; Williams et al., 1988). According to Ruddiman and Raymo (1988) the 100,000 year eccentricity rhythm became most dominant after $0.45 \mathrm{Ma}$.

\section{SUMMARY}

Micropaleontological and stable isotopic studies of ODP Site 653 in the Tyrrhenian Basin provide a detailed record of the post-Messinian paleoenvironmental history of the western Mediterranean. The last 5 million years were marked by a number of distinct paleoceanographic events which culminated in the present day hydrographic setting. These include:

1. Following the Messinian salinity crisis, the Mediterranean was repopulated by a warm-water plankton assemblage. Benthic foraminifera indicate restricted circulation and low bottom water oxygen conditions in the earliest Pliocene.

2. Although dominated by warm water plankton, the early Pliocene was not a time of uniform or stable climatic conditions. Throughout the early Pliocene there appears to have been good deep water exchange between the Atlantic and the Mediterranean.

3. The first indications of a climatic cooling occur in the early Pliocene at approximately 4.1 and $3.8 \mathrm{Ma}$. The introduction of both warm-temperate planktonic foraminifera and coolerwater discoasterids occurs at this time.

4. A distinct cooling occurs at approximately $3.1 \mathrm{Ma}$ with the warm-temperate fauna replacing the warm-water fauna. An increase in the abundance of the cool-water Coccolithus pelagicus also occurs at this time.

5. A further cooling of climatic conditions occurs in the Mediterranean at $2.4 \mathrm{Ma}$ in response to increased glaciation of the Northern Hemisphere. This cooling may have resulted in increased aridity and greater evaporation over the Mediterranean. As a consequence, a negative water balance may have been established between the Mediterranean and Atlantic at this time. This marks the beginning of the modern hydrographic regime in the Mediterranean (anti-estuarine circulation). A significant decrease in discoaster abundance is also associated with this cooling at $2.4 \mathrm{Ma}$.

6. A local or regional cooling occurs within the Mediterranean area around the Pliocene-Pleistocene boundary. At this time cool-water planktonic foraminifera become very abundant.

7. An increase in glacial-interglacial contrasts occurs in the middle Pleistocene $(0.8-0.9 \mathrm{Ma})$. This reflects an intensification of Northern Hemisphere glacial conditions.

8. The endemic Mediterranean benthic foraminiferal fauna becomes fully established by the middle Pleistocene.

\section{REFERENCES}

Backman, J., and Pestiaux, P., 1986. Pliocene discoaster abundance variations, Deep Sea Drilling Project Site 606: biochronology and paleoenvironmental implications. In Ruddiman, W., Kidd, R., et al., Init. Repts. DSDP, 94: Washington (U.S. Govt. Printing Office), 903-910.

Berggren, W. A., Kent, D. V., Flynn, J. J., and Van Couvering, J. A., 1985. Cenozoic geochronology. Geol. Soc. Am. Bull. 96:1407-1418.

Chamley, H., 1975. Sedimentation argileuse en mer Tyrrhenienne au Plio-Pleistocene d'apres l'etude du forage JOIDES 132. Bull. Groupe Fr. Argiles. 27:97-137.

1983. Marine and continental antagonistic influences in Mediterranean Neogene to Recent clay sedimentation. Utrecht Micropaleontol. Bull. 30:71-90.
Ciaranfi, N., and Cita, M. B., 1973. Paleontological evidence of changes in the Pliocene climates. In Ryan, W.B.F., Hsü, K. J., et al., Init. Repts. DSDP, 13: Washington (U.S. Govt. Printing Office), 13871399.

Cita, M. B., and Zocchi, M., 1978. Distribution patterns of benthic foraminifera on the floor of the Mediterranean Sea. Oceanol. Acta 1: 445-462.

Cita, M. B., Chierici, M. A., Ciampo, G., Zei, M., d’Onofrio, S., Ryan, W.B.F., and Scorziello, R., 1973. The Quaternary record in the Tyrrhenian and Ionian Basins of the Mediterranean Sea. In Ryan, W.B.F., and Hsü, K. J., et al., Init. Repts. DSDP, 13: Washington (U S. Govt. Printing Office), 1263-1339.

Cravatte, J., and Suc, J. P., 1981. Climatic evolution of north western Mediterranean area during Pliocene and early Pleistocene by pollen analysis and foraminifera of drill AUTAN 1. Chronostratigraphic correlations. Pollen and Spores 23:247-258.

Emiliani, C., 1966. Paleotemperature analysis of Caribbean cores P6304-8 and P-6304-9 and a generalized temperature curve for the past 425,000 years. J. Geol. 74:109-124.

Forbes, E., 1846. On the connection between the distribution of the existing fauna and flora of the British Isles and the geographical changes which have affected their area, especially during the epoch of the Northern Drift. Great Britain Geological Survey Mem. 1:336-432.

Hodell, D. A., and Kennett, J. P., 1986. Late Miocene-early Pliocene stratigraphy and paleoceanography of the South Atlantic and southwest Pacific Oceans: a synthesis. Paleoceanography 1:285-312.

Keigwin, L. D., Jr., 1979. Late Cenozoic stable isotope stratigraphy and paleoceanography of DSDP Sites from the east equatorial and north central Pacific Ocean. Earth Planet. Sci. Lett. 45:361-382. 1982. Stable isotope stratigraphy and paleoceanography of Sites 502 and 503. In Prell, W. L., Gardner, J. V., et al., Init. Repts. DSDP, 68: Washington (U.S. Govt. Printing Office), 445-453.

1987. Pliocene stable isotope record of DSDP Site 606: sequential events of ${ }^{18} \mathrm{O}$ enrichment beginning at 3.1 MA. In Ruddiman, W. F., Kidd, R. B., et al., Init. Repts. DSDP, 94: Washington (U.S. Govt. Printing Office), 911-920.

Loubere, P., 1987. Changes in mid-depth North Atlantic and Mediterranean circulation during the late Pliocene. Isotopic and sedimentological evidence. Mar. Geol. 77:15-38.

Lutze, G., and Coulbourn, W., 1983. Recent benthic foraminifera from the continental margin of northwest Africa: community structure and distribution. Mar. Micropaleontol. 8:361-401.

Massiota, P., Cita, M. B., and Mancuso, M., 1976. Benthonic foraminifers from bathyal depths in the eastern Mediterranean. Maritime Sediments Spec. Publ., 1:252-262.

McIntyre, A. and Bé, A.W.H., 1967. Modern Coccolithophoridae of the Atlantic Ocean. I. Placoliths and cyrtoliths. Deep Sea Res. 14: 561-597.

Pasini, G., Colalongo, M., and Sartoni, S., in press. Sedimentology, biostratigraphy, magnetostratigraphy, biochronology and radiometric dating of the Vrica section in Calabria (Italy). In Van Couvering, J. (Ed.), The Pliocene/Pleistocene Boundary: Definition and Worldwide Correlation: Cambridge (Cambridge Univ. Press).

Pisias, N. G., and Moore, T. C., 1981. The evolution of Pleistocene climate: a time series approach. Earth Planet. Sci. Lett. 52:450-458.

Prell, W. L., 1982. Oxygen and carbon isotope stratigraphy for the Quaternary of Hole 502B: evidence for two modes of isotopic variability. In Prell, W. L., Gardner, J. V. et al., Init. Repts. DSDP, 68: Washington (U.S. Govt. Printing Office), 455-464.

1984. Covariance patterns of foraminiferal $\delta^{18} 0$ : An evaluation of Pliocene ice volume changes near 3.2 million years ago. Science 226:692-294.

Ruddiman, W. F., and Raymo, M. E., 1988. Northern Hemisphere climate regimes during the past $3 \mathrm{Ma}$ : possible tectonic connections. Philos. Trans. R. Soc. London. 318:411-430.

Ruddiman, W. F., Raymo, M., and McIntyre, A., 1986. Matuyama 41,000-year cycles: North Atlantic Ocean and northern hemisphere ice sheets. Earth Planet. Sci. Lett. 80:117-129.

Ruddiman, W. F., McIntyre, A., and Raymo, M., 1987. Paleoenvironmental results from North Atlantic sites 607 and 609. In Ruddiman, W., Kidd, R., et al., Init. Repts. DSDP, 94: Washington (U.S. Govt. Printing Office), 855-878.

Ryan, W.B.F., Hsü, K. J., et al., 1973. Init. Repts. DSDP, 13 Washington (U.S. Govt. Printing Office). 
Selli, R., 1967. The Pliocene-Pleistocene boundary in Italian marine sections and its relationship to continental stratigraphies. In Sears, M. (Ed.), Progress in Oceanography (Vol. 4): New York (Pergamon Press), 67-86.

Shackleton, N. J., et al., 1984. Oxygen isotope calibration of the onset of ice-rafting and the history of glaciation in the North Atlantic region. Nature, 307:620-623.

Shackleton, N. J., and Opdyke, N. D., 1973. Oxygen isotope and paleomagnetic stratigraphy of equatorial Pacific core V28-238: oxygen isotope temperatures and ice volumes on a 105 year and 106 year scale. Quat. Res. 3:39-55.

1976. Oxygen isotope and paleomagnetic stratigraphy of $\mathrm{Pa}$ cific core V28-239: Late Pliocene to Latest Pliocene. In Cline, R. M., and Hays, J. D. (Eds.), Investigations of Late Quaternary Paleoceanography and Paleoclimatology: Geol. Soc. Am. Mem., 145: 449-464.

, 1977. Oxygen isotope and paleomagnetic evidence for early Northern Hemisphere glaciation. Nature, 270:216-219.

Shipboard Scientific Party, 1987. Site 653: Cornaglia Terrace. In Kastens, K., Mascle, J., et al., Proc. ODP, Init. Repts., 107: College Station, TX (Ocean Drilling Program), 599-745.

Suc, J. P., 1984. Origin and evolution of the Mediterranean vegetation and climate in Europe. Nature, 307:429-432.

Tauxe, L., Opdyke, N. D., Pasini, G., and Elmi, C., 1983. Age of the Plio-Pleistocene boundary in the Vrica section, southern Italy. $\mathrm{Na}$ ture 304:125-129.

Thierstein, H., Geitzenauer, K., Molfino, B., and Shackleton, N., 1977. Global synchroneity of late Quaternary coccolith datum levels: validation by oxygen isotopes. Geology, 5:400-404.

Thunell, R. C., and Belyea, P., 1982. Neogene planktonic foraminiferal biogeography of the Atlantic Ocean. Micropaleontology, 28:281298.
Thunell, R. C., and Williams, D. F., 1983a. The stepwise development of the last 5.0 million years. Sed. Geol., 23:67-79.

1983b. The stepwise development of Pliocene-Pleistocene paleoclimatic and paleoceanographic conditions in the Mediterranean: oxygen isotope studies of DSDP Sites 125 and 132. Utrecht Micropaleontol. Bull., 30:11-127.

Thunell, R., Williams, D., and Howell, M., 1988. Atlantic-Mediterranean water exchange during the late Neogene. Paleoceanography, 2: 661-678.

Van der Zwaan, G. J., 1983. Quantitative analyses and the reconstruction of benthic foraminiferal communities. Utrecht Micropaleontol. Bull., 30:49-69.

Vergnaud Grazzini, C., 1985. Mediterranean late Cenozoic stable isotope record: stratigraphic and paleoclimatic implications. In Stanley, D. J. (Ed.), Geological Evolution of the Mediterranean Basin: (Springer-Verlag), 413-451.

Williams, D. F., Thunell, R. C., Tappa, E. J., Rio, D., and Raffi, I. Chronology of the Pleistocene oxygen isotope record: 0-1.88 million years before present. Palaeogeogr., Palaeoclimatol., Palaeoecol., 64: 221-240.

Zachariasse, W. J., and Spaak, P., 1983. Middle Miocene to Pliocene paleoenvironmental reconstruction of the Mediterranean and adjacent Atlantic Ocean: planktonic foraminiferal record of southern Italy. Utrecht Micropaleontol. Bull., 30:91-110.

Zagwin, W. H., 1974. The Plio-Pleistocene boundary in western and southern Europe. Boreas, 3:75-97.

Date of initial receipt: 20 April 1988

Date of acceptance: 8 March 1989

Ms 107B-154 